\title{
リグニンの有効利用
}

編者都大学工学部 佐 田栄 三
(絑)日本紙パルプ研究所 浅 岡 宏

\section{Effective Utilization of Lignin}

\author{
Eizo Sada \\ Department of Chemical Engineering, Kyoto University \\ Hiroshi Asaoka \\ Japan Pulp \& Paper Research Institute, Inc.
}

Although lignin in wood materials is to be separated as much as approximately a half of the amount of pulp through pulping processes, currently the chemical value of isolated polymeric lignin has not yet been effectively utilized. It has been desired to develop the processes for utilization of lignin in view of its chemical substance, i.e. highly complex polymer.

In this review, first the outline of the present situation of lignin utilization in pulp and paper industries is presented in Section 1. Afterwards, the following three sections have been devoted from the standpoints of effective and potential utilization of lignin : Present situation of utilization of effective components and possibility or potentiality of utilization of derived components as chemical feedstocks (Section 2) Decomposition processes of lignin (Section 3) Possibility of utilization of decomposed components (Section 4).

In Section 2, two typical reactions of lignin utilized for separation, i.e. acid catalyzed decomposition of ether likages and reductive decomposition of $\beta$-ether have been briefly described and the features of both reaction sequences offered along with practical applications. The necessity to clarify both the decomposition and condensation reactions quantitatively, that is, from the view point of chemical kinetics has been pointed out, because active sites for condensation reaction are apt to be still left after completion of both the reactions. Further, the steam explosion process of lignin, which is a practical process utilizing decomposition reaction of ether linkages is outlined and reactions and separations of derived components are explained to search for a possibility of their effective utilization.

The first part of Section 3 is devoted to introduce several trials to degradate lignin chemically and thermally (pyrolysis) for chemical utilization. Hydrogenated decomposition, oxidative decomposition and production of catechol through a nucleophilic substitution reaction are reviewed as to chemical degradation. In the remaining part of this section, the biodegradation of lignin, i.e. the microbiology of lignin degradation, specifically lignin-degrading microbes and enzyme systems of lignin degradation, is reviewed. The latest trend and problems in the relevant fields are outlined and the long-term goals of biological processing of lignin are pressented.

In Section 4, a feasibility study for production of polyoxyphenylene (or polyphenylene oxide, PPO) which is an important engineering plastic is given. The production of PPO is regarded as one of the promising processes for utilization of lignin-derived chemicals when the cost of lignin as well as the marcket scale of the product is taken into account. 
Keywords : Lignin, Hydrogenated decomposition, Oxidative decomposition, Pyrolysis, Steam explosion process, Biodegradation and Polyoxyphenylene

\section{1.はじめに}

\section{1 リグニン利用研究の方向性}

この報告は昭和 61 年から 63 年にわたる化学工学協 会の「紙パ産業におけるプロセス工学的問題調査」研 究会における検討をまとめたものである。この研究会 は昭和 57 年に東京農工大学の乙竹直教授 (当時) が日 本紙パルプ研究所の浅岡宏社長と諮り設置されたもの である。当初は, 紙・パルプ製造プロセスにおける化 学工学的な諸問題として, (1)パルプスラリーに関連し た機械的・力学的諸問題, (2)用水および環境に関する 問題および(3)製造プロセスの省エネルギーについて調 査検討を行い，既に報告書が与えられている1)。

昭和 61 年から研究会の第 2 期に入り, 第 1 期の成果 を踏まえて，(1)木材成分の高度利用，(2)パルプ慜濁液 の物性および(3)無塩素漂白を中心として調査研究を 行った。本報告はこれらの課題中，とくにリグニンの 利用に関する調査のまとめである。

既に良く知られているように，樹種にもよるが，木 材は 40〜50\%のセルロース，5２0\%のへミセルロー ス，20３0\%のリグニン，2～5\%の樹脂などから構成 されている。すなわち, パルプの生産のさいに, パル プ量の約半量のリグニンを木材から分離・除去しなけ ればならない。現在, わが国では約 800 万 $\mathrm{t}$ の化学パ ルプが生産されているが, これに伴い約 400 万tのリ グニンが生じていることとなる。木材中のリグニンは, これまでリグニンの物質を活かした利用は殆ど行われ ず，主として，パルプとしてセルロースから分離する ことなく，リグニンを含有したまま抄紙されたり，木 材から化学的にリグニンを分離する場合でも蒸解剤の 回収のために燃焼して熱エネルギーとして利用されて きている。ほかに, 道路舗装用バインダー, コンクリー 卜減水剤, 水処理剂, 分散剂などとしても利用されて いるが，その量は極めて少ない。これらはリグニン化 合物の粘着性, 分散性などを利用しているに過ぎず, リグニンの化学構造に基づいた有機工業薬品の原料と しての積極的な利用およびプロセスの開発が望まれる。 最近, フェニルプロパン単量体のエーテル結合で架 橋したリグニンの骨格構造が明らかにされ, 種々な構 造モデルが与えられている ${ }^{21}$ 。これらの構造を芳香族 核の重縮合に基づく石炭の骨格構造モデルと比較する と, 両者の骨格の顕著な類似性および石炭に対してリ グニンの水素および酸素含有量の多さを改めて認識さ
せられる。これは, 植物が長い年月の間に, その水素 および酸素含有量が低下し, 石炭化が進むとする石炭 の生成過程からは当然のことであろう。リグニンの化 学的な分解に基づく有効成分の利用に際して, 石炭の 同様なプロセスはさまざまな示唆を与えてくれること を示している。石炭に比べて水素および酸素含有量が 多い点からも, パルプ製造過程で生じるリグニン化合 物は, 種乃な有機工業製品の有力な原料と考えるべき であろう。石炭に対しては，その高度利用を目指して， 既に水素添加分解などに基づく石炭の直接液化により 液体燃料の合成, 有機工業薬品の製造プロセスの開発 が進められている。これに対して, リグニンの水素化 分解により，有用な有機工業薬品を製造しようとする 試みは, これまでにも行われてきたが石炭の場合に比 べて少ない。対象とするリグニンの出発物質, 水素化 分解の条件などにより, フェノール, クレゾール類, カテコール類ならびにそれらの誘導体などを種々な化 合物を含む複雑な組成の混合物を生じ, それらの量比 も著しく変動する。工業プロセスとして展開するため には, 触媒の探索, 分解条件の選定などにより, 単純 な組成の生成物の製造プロセスを開発するか, 複雑な 組成の混合物から比較的単純な組成の物質を得る分離 プロセスを開発するかにかかっている。種々な分野の 科学者, 技術者の協力による現象の解明とそれに基づ くプロセスの開発が望まれる。

\section{(京都大学工学部 佐田栄三)}

\section{2 リグニン利用と紙パルプ産業}

木材からパルプそして紙が製られるようになってか ら 100 150 年の年月がたっている。その間リグニンは いわば邪魔者であり，いかにしてリグニンもしくはそ の影響を除去するかに技術開発の目的があった。機械 パルプは木材を磨砕して木材繊維を分離するが, 多量 のリグニンが繊維中に残存する。この種のパルプを原 料とする新聞用紙などは長期の保存に適さず強度も弱 い。木材中のリグニンを溶出分離して製造する化学パ ルプは極めて用途が広い。反面, 単離したリグニンの 処分に問題がのこる。化学パルプの現実の製造技術と してサルファイト法 $(\mathrm{SP})$ とクラフト法 $(\mathrm{KP})$ とがあ る。SP は先行技術であり, ある時期までは優勢であっ たが, 現在では KP が主流を占めている。その原因は いろいろ考えられるが, 最大の要因として KPはその プロセス構成上クローズドシステムをとらざるを得な 
い，具体的にはリグニン成分を含むいわゆる黒液が濃 縮燃焼されることがあげられる。この過程においてリ グニンの処分問題が解決されるわけである。 SP は遂 にこの問題を技術的に処理できなかった。

リグニンは木材成分のうち $20 \sim 30 \%$ 占める。これ はセルロースに対して半分近くに相当する。もしリグ ニンが木材繊維中にあって，しかもセルロースなみに 支障なく挙動してくれれば一番よい。この方向を指向 するものとして CTMP から BCTMP が考えられて いる。高収率パルプの保存漂白といわれるものである。 一方, 単離されたリグニンが有効に利用され, 極言す ればセルロース以上の付加価值が期待できるなら，化 学パルプとの併産も考えられる。最終的には木材成分 の高度利用ということであろう。

リグニンについて系統的な研究がはじまったのは僅 か半世紀以前のことであり, それがフェニルプロパン 単量体の重合物であるとはっきり認識されたのは大戦 終結前後という ${ }^{3)}$ 。戦後 40 年間, リグニン化学の研究 は世界各所で実施され各種の知見が集積されてきた。 それにもかかわらずリグニンの構造をはじめその全体 像は未だはっきりしていない。ましてその利用の研究 は極めて断片的である。構造研究の主たる手法にリグ ニンを各種の手段で分解し, その生成物を検索するこ とがある。その知見を利用して各種フェノール類を取 得する，あるいはそれら化合物を出発原料として有用 物質を誘導することはその膨大な潜在生産可能量を考 えあわせ企業化につながる可能性は極めて大きいだろ う。しかしこれに関し工学的立場からの検討はほとん どなされていない。現在, 芳香族系原料は石油系と鉄 鋼業のコークス製造副産物としての石炭系がある。も し木質系のリグニンが参入するとすれば，まず経済的 優位性が保証されねばならぬだろう。品質性能につい ても知見はそしい。

現状ではリグニンについて特別の考虑をしなくてす む KP プロセスがある以上, リグニンの利用あるいは ウッドケミカルスなどは将来の夢としてたてまつって おけばよいではないかというのが, この業界での大方 の本音であろう。しかし日本の紙パルプ産業, あるい は経済全般をとりまく情勢は今後ますますきびしく予 断を許さないものと思われる。我々は資源問題, 国際 競争力, エネルギー事情さらには科学技術の進歩等々 による状況の変化がおこり得ることを想定し, 考えら れる可能性をあくまで追究しておく必要がある。

(慄)日本紙パルプ研究所 浅岡 宏)

\section{2.リグニン分離法とその可能性}

\section{1 成分分離過程でのリグニンの反応}

木材は，その主要三成分であるセルロース，へミセ ルロースおよびリグニンが細胞間あるいは細胞壁内に おいて, 化学的または物理的に強固に結びつけられた ものである。従って，これらの三成分を分離して，そ れぞれを別々に有効利用しようとするならば，何らか の化学的処理を施さなければならない。

天然の状態でのリグニンの構造は, 不明な点も残さ れてはいるものの, かなり明らかにされている。しか し問題は成分分離のために施す化学的処理により, ど のような構造変化をもたらすかである。分離した後の 成分の利用に際して, 好ましい構造変化でなければな らない。

本来ならば，リグニンの利用を考えた上で，利用上 好ましい構造変化をもたらしながら, 成分分離を行う のが望ましい。しかしながら, 現在のところ定着した リグニンの大量用途が見出されているわけではないの で，成分分離とリグニンの用途開発の双方を考えなが ら模索していくしかないであろう。

ここでは, 現在知られているいくつかの代表的成分 分離反応について, 成分分離過程あるいはその後に残 されたリグニンの構造を見てみる。特にリグニンの縮 合反応活性点に着眼して気が付いた事を述べ，今後の 課題を考えてみることにする。

成分分離のためのリグニンの反応の代表的な例とし て，まず酸触媒によるエーテル開裂反応が挙げられる。 酸触媒によるエーテル開裂反応を利用した成分分離法 には, 蒸煮・爆砕やオルガノソルブパルプ化などがあ る。酸性サルファイト法やハイドロトロピック法など でも，一部はこのような反応が起こっているであろう。 蒸煮・爆砕法については, エーテル結合のホモリティッ クな開裂反応が提案されているが別項にゆずる。

図 1 に，エーテル開裂後にリグニン中に残される構 造を示した。中間体としてのカルボニウムイオンの安 定性から, 当然のことながら $\alpha$-エーテルが先に開裂を 受ける。結果として〔 I 〕が生成する。これは非常に 不安定な構造であり，他のリグニンュニットと縮合反 応をするか, あるいはアリールエーテルを経て $\beta$-エー テルの開裂後構造〔II〕になる。〔II〕はさらに種々の 反応を経て，いわゆる七バートのケトン類を与える。 これらのカルボニル化合物は, 他のリグニンユニット との酸縮合反応の活性点にもなる。

このように酸触媒によるエーテル開裂反応を用いた 場合には, 反応後に必ずリグニンの縮合反応活性点を 


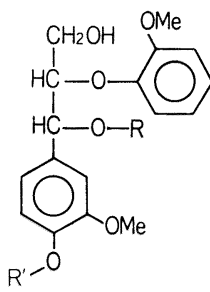

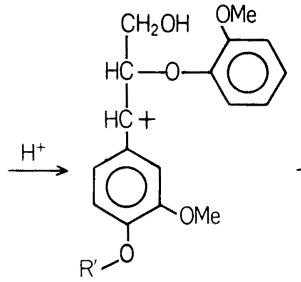

(I)

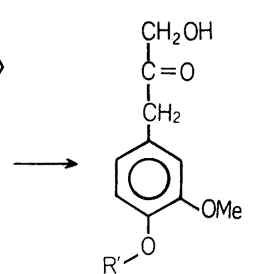

(II)

図 1 酸触媒によるエーテル開裂

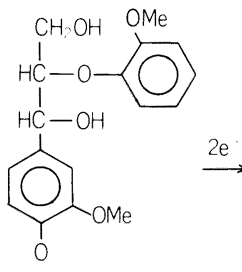

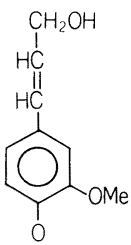

[III]

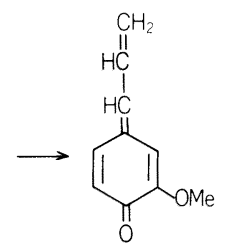

〔V
図 2 アルカリ性下での還元的エーテル開裂

残してしまう。

もう一つの代表的成分分離反応の例として, アルカ リ性下での還元的 $\beta$-エーテル開裂反応を見てみる。こ れは, クラフト法やアントラキノン蒸解に見られるも のである。図 2 に示すように, 反応後のリグニン中に は構造〔III)が残ることになる。この構造も，(IV)の ようなキノンメチド構造をとり縮合反応の活性点とな る。

以上の代表的な 2 例でも分かるように，成分分離に リグニンの分解反応を用いると，反応後に非常に活性 な縮合反応点を残してしまうことが多い。反応が複雑 であるために，開裂反応と縮合反応を定量的に，すな わち速度論的に扱った報告は見当らないが，木材成分 を有効利用していくための今後の課題の一つであろう。 また一般的に成分分離のしにくい針葉樹材についても， このような縮合反応が問題なのか, あるいは最初の開 裂反応自体が起こりにくいのか, 今後の課題として考 えていく必要があると思う。

(農水省森林総合研究所 細谷修二)

\section{2 爆砕処理による木材成分の分離とその有効 利用}

世界的に森林の減少が問題になっている今日，木材 資源の効率的利用法の開発は木材研究者に課せられた 重要な使命である。未利用木質残渣の有効利用と紙パ ルプ関連分野における革新的な技術開発がますます要 望されている。木材資源を効率的に利用するには化学 的性質の異なる成分（セルロース，へミセルロース，
リグニン)の分離が不可欠であり, 爆砕処理はこのウッ ドリファイナリーのための有効な前処理法である。こ こでは爆砕処理による木材主要成分の反応と分離およ びその有効利用の可能性について概説する。

\section{1）爆砕処理による木材主要成分の反応と分離}

爆砕法とは木材を $20 \sim 40 \mathrm{~kg} / \mathrm{cm}^{2}, 200 \sim 250^{\circ} \mathrm{C}$ の飽 和水蒸気で数分間処理した後, 爆発的に圧力を解放す ることにより組織を破壞し, 解緎または微粉砕する方 法であり, いわゆる木材のポン菓子製造法である。こ の処理によりへミセルロースは急速に加水分解されて 低分子化し, 水に可溶となり組織から溶出される ${ }^{4)}$ 。広 葉樹の場合, 主な分解物はキシロースであり, 一部は 脱水されてフルフラールに変換される。またへキソー スからは5-ヒドロキシメチルフルフラールが生成す る。これらはフラン樹脂等の工業原料として利用法が 確立されており, また抗菌作用も強く防腐剂への利用 も検討されている。キシロースやキシロオリゴ糖は志 水等によって蒸煮・爆砕材からの精製法やその利用法 について研究されており, 低カロリーの甘味料や食品 添加物，医薬用としての応用が期待される5)。

リグニンはへミセルロースに比べて反応が遅く， $\alpha-$ 及び $\beta$-エーテル結合が徐々に切断されて処理時間の 増加とともに低分子化し，メタノールやジオキサン等 の有機溶媒やアルカリ水溶液に可溶となる(図 3 )。こ

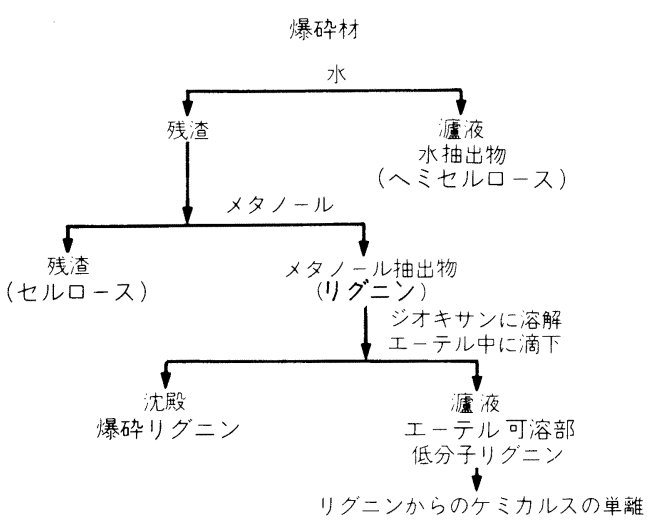

図 3 爆砕材各成分の分画フローチャート 


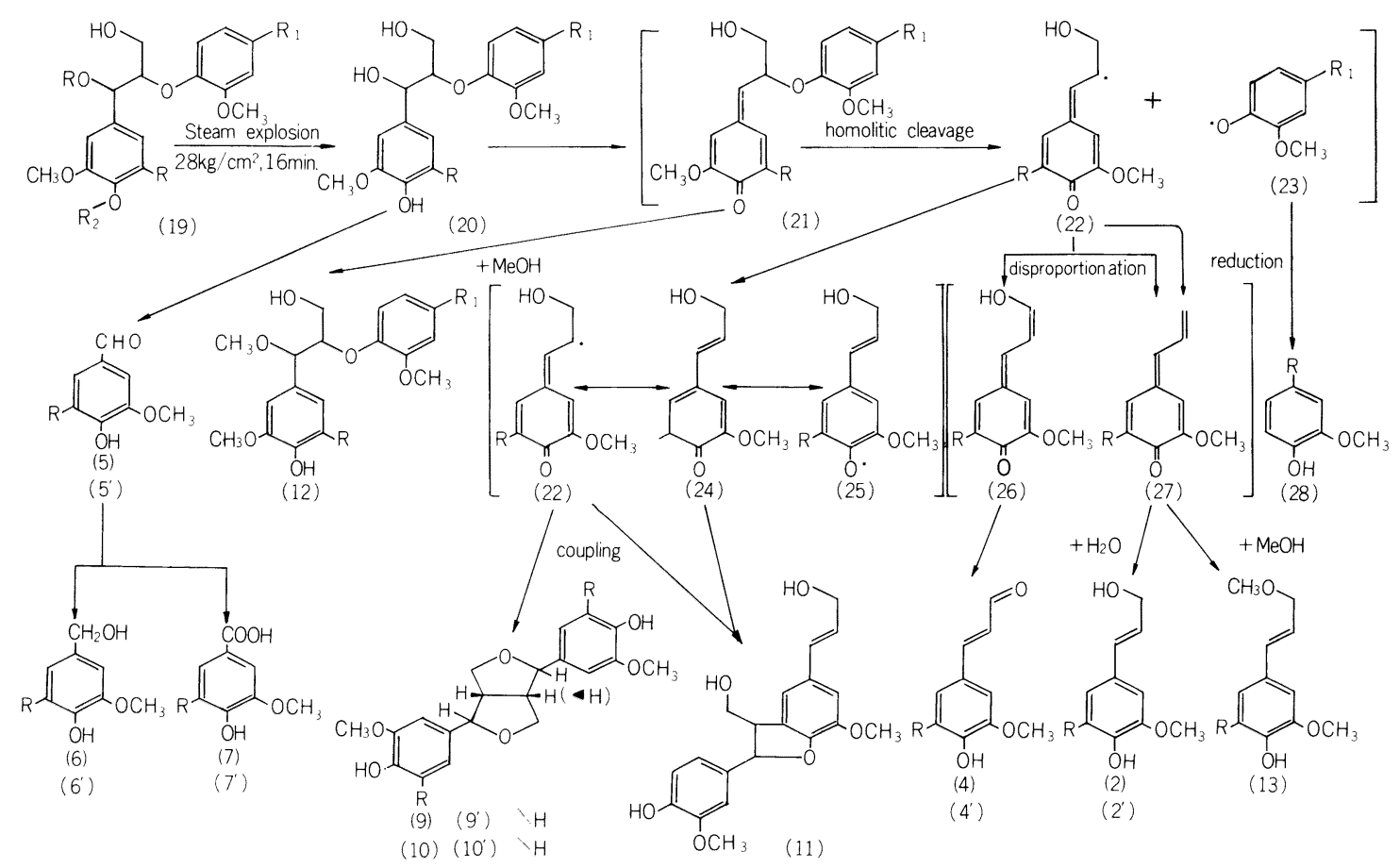

図 4 爆砕処理におけるリグニンの反応機構

のようにして得られた爆砕リグニンの分子量は 28 $\mathrm{kg} / \mathrm{cm}^{2}-4$ 分処理のもので約 2,000 であり, フェノー ル性水酸基量は $\mathrm{C}_{6}-\mathrm{C}_{3}$ 当たり 0.4 と増加している。こ のリグニンの約 40\%はエーテルに可溶の低分子フラ クションであり,ここからシリンガレジノール, シナッ プアルデヒド, コニフェリルアルデヒド, シナピール アルコール, コニフェリールアルコール, シリンガル デヒド，バニリンなどが主生成物として得られる。こ のことから爆砕処理によるリグニンの反応機構はアシ ドリシスではなく, $\beta$-エーテル結合のホモリティック な開裂反応であり, 生成したラジカルはカップリング してレジノールやフェニールクマランのような安定な 2 量体に転換されるか, 不均化反応によってシナピル アルコールやコニフェリールアルコールとそれらのア ルデヒドに変換される(図4)。もとのリグニン中には レジノール構造はそれほど多く含まれていないが, 爆 砕処理によって二次的に $\beta-\mathrm{O}-4$ 構造から変化して生 成するため, その収率は高く, その分離精製も比較的 容易である6)。またこの化合物は生理活性を有するた めにリグニンの有効利用法として将来有望である。

一方, 七ルロースは結晶性であり, 水蒸気とは直接 反応しにくく，長時間加熱しないかぎりグルコースま でに分解されるようなことはないが, 非晶領域におい て部分的に加水分解されその分子量を低下寸る。その
結果, セルロース分子鎖の歪が解除され非晶部が結晶 に熱再配列し，七ルロースの結晶性を向上する。また 高温処理によりセルロースの結晶形態が木材の Ib 型 に近い不明瞭な形態から Ia 型の明瞭な結晶に変換さ れる7)。このように爆砕処理されたセルロースは化学 反応性や酵素反応性が改善され，またアルカリによる マーセル化を容易にし ${ }^{8)}$ ，ある条件下では爆砕セル ロースはアルカリに可溶となる ${ }^{9)}$ 。従って木材の飼料 化や酵素糖化の前処理として爆砕処理は有効であり， またセルロース誘導体の合成原料や食品添加物として 爆砕セルロースは有用されるであろう。

以上のように，爆砕処理は木材中の各構成成分に対 して非常に効果的に作用し，各成分を低分子化し，水 及び有機溶媒による抽出によって木材構成成分を効率 よく分離することができる（表 1 )。

\section{2）爆砕リグニンの有効利用}

爆砕リグニンの利用に関してはまだ研究段階である が, 他の工業リグニンと比較して分離精製が容易であ り, 反応性が高く, 有害な脱リグニン試薬等を含んで いないため種々の分野への利用が考えられる。これま でに研究された爆砕りグニンの応用について概説する。

(1) リグニンの生理活性

爆砕リグニンの有効利用について，特に興味ある研 究としてその生理活性に関するものがある。Wayman 
表 1 シラカンバ爆砕材の抽出物量および残存りグニン量 ${ }^{4}$

\begin{tabular}{|c|c|c|c|c|c|c|c|c|}
\hline \multicolumn{2}{|c|}{ 処 理 条 件 } & \multicolumn{3}{|c|}{ 抽出物量 ／ 爆砕材 } & \multicolumn{3}{|c|}{ 収率／ジオキサン抽出物 } & \multirow{2}{*}{$\begin{array}{l}\text { ジオキサン } \\
\text { 抽出残渣中 } \\
\text { の残存リグ } \\
\text { ニン }(\%)\end{array}$} \\
\hline $\begin{array}{l}\text { 圧 力 } \\
\mathrm{kg} / \mathrm{cm}^{2}\end{array}$ & $\begin{array}{c}\text { 時 間 } \\
\min \end{array}$ & $\begin{array}{c}\text { 水 } \\
\mathrm{EXW}(\%)\end{array}$ & $\begin{array}{l}\text { メタノール } \\
\operatorname{EXL}(\%)\end{array}$ & $\begin{array}{l}\text { ジオキサン } \\
\operatorname{EXD}(\%)\end{array}$ & $\begin{array}{c}\mathrm{DL} \\
(\%)\end{array}$ & $\begin{array}{c}\text { DWL } \\
(\%)\end{array}$ & $\begin{array}{l}\mathrm{DW} \\
(\%)\end{array}$ & \\
\hline $20-$ & 1 & 27.9 & 8.5 & 27.1 & 9.6 & 1.6 & 88.8 & 15.1 \\
\hline $24-$ & 1 & 25.8 & 10.8 & 41.2 & 12.2 & 1.2 & 86.6 & 12.8 \\
\hline $28-$ & 1 & 29.3 & 13.7 & 47.1 & 19.4 & 1.2 & 78.4 & 12.2 \\
\hline $28-$ & 2 & 29.2 & 18.3 & 58.7 & 25.7 & 1.5 & 72.8 & 9.7 \\
\hline $28-$ & 4 & 29.4 & 23.7 & 58.1 & 40.1 & 1.9 & 58.0 & 5.0 \\
\hline $28-$ & 8 & 18.8 & 29.2 & 56.0 & 48.0 & 1.8 & 50.2 & 5.0 \\
\hline $28-$ & 16 & 22.0 & 26.2 & 54.8 & 44.9 & 1.9 & 53.2 & 2.7 \\
\hline 未 処 & 理 & - & - & - & - & - & - & 22.3 \\
\hline
\end{tabular}

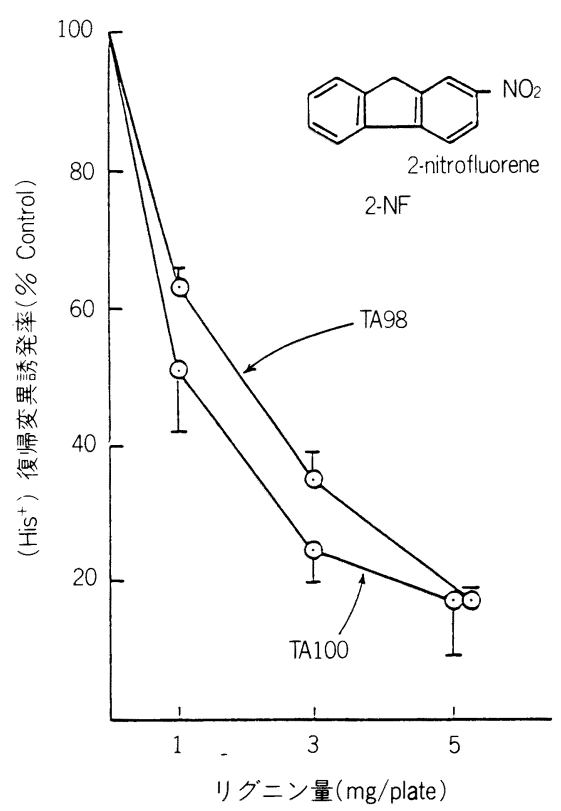

図 5 TA 98 およびTA 100 を用いた場合の2ニトロフルオレンに対する爆砕リグニン （アルカリ抽出物）の抗変異原性

等は飼料中に爆砕リグニンとラクチュロースを混入し てハムスターに与えると胆汁酸の分泌が高くなり，血 液中のコレステロールが $1 / 3$ に減少し, 胆石もできな いことを示した ${ }^{10)}$ 。また爆砝りグニンには 2-ニトロフ ルオレンやニトロソグアニジンのような発癌珮による サルモネラ菌の突然変異を抑制する, かなり強い抗变 異原活性があり, 一方, リグニン自体は毒性や変異原 性がないことが確認されており, 将来, 抗癌剛として の利用が期待される(図 5 )。この活性成分としては フェニールクマラン, レジノールのような環状化合物
が考えられるため, 分解生成物とその類似化合物の抗 変異原性が調べられ，p-ヒドロキシフェニル核をもつ クマランやレジノール構造に強い活性が見い出され た ${ }^{11)}$ 。

(2) リグニンからのケミカルスの単離

爆砕リグニンはその 40 50\%がエーテル可溶の低 分子フラクションであり, 主としてモノマーとダイ マーから成り, 容易に分解生成物を分離することが可 能である。広葉樹のこのフェノール性フラクションか らはd,1-シリンガレジノール, d,1-エピシリンガレジ ノール, デヒドロジコニフェリールアルコール, バニ リン，シリンガルデヒド，コニフェリールアルデヒド， シナップアルデヒド，コニフェリールアルコール等が 単離された (図 4$)^{4)}$ 。これらの生成物中最も多量に得 られ，また最も興味がある化合物はシリンガレジノー ルであり，これはリグニンとして広葉樹や草本類中に 配糖体あるいはアグリコンとして少量存在している。 最近, 朝鮮ニンジンと同属の植物であるエゾウコギの 根の抽出成分が強壮剤や生態防御作用増強剤として注 目されているが，この活性成分中には，シリンガレジ ノールとその配糖体が多く存在することが報告されて いる12)。しかしこれらの植物体中にはシリンガレジ ノール誘導体がわずか $0.02 \%$ 程度含まれているのみ であり，これを純粋に単離するには高度な分離技術が 必要である。広葉樹の爆砕処理によってリグニン中の シリンギル核をもつ $\beta$-エーテル結合がホモリティッ クに開裂し，シリンガレジノールに変換されるため, その収率は木材当たり約 $1 \%$ と高くなり，しかも爆砕 材からのリグニンの抽出や, 低分子フラクションの分 別が容易であることから，シリンガレジノールの精製 工程は容易であり，その収率はエーテル可溶部の約 $10 \%$ にもぶ13)。シリンガレジノールをこのように高 
収率で得る方法は今のところ爆砕処理のみであろう。 これまで, あまり有効に利用されていなかったリグニ ンから付加価値の高い生理活性物質への転換利用が可 能となった。また爆砕処理におけるリグニンの反応機 構が明らかになったことから, 反応条件を制御してシ ナピールアルコールやコニフェリールアルコールを収 率よく生成できる可能性もある。コニフェリールアル コールの $\gamma$-ベンジルエステルは勝れた香料であり,こ の合成原料を爆砕リグニンから得ることが期待できる。

(3) リグニン炭素緎維

爆砕リグニンの炭素纎維化に関する研究は須藤等に よって行われており, 繊維化のために熱に不安定な エーテル結合を取り除き，また剛直な縮合型構造を柔 軟化するために水素添加分解が行われ, 熱溶融法で緎 維化した後, 熱安定化処理される。繊維強度はピッチ 系炭素繊維程度であるが, 今後, 高強度化や機能性の 付与等の研究に期待が持たれる ${ }^{14)}$ 。

(4) リグニンからの接着剤や樹脂の製造

Glasser 等はヒドロキシプロピル化した爆砕リグニ ンを用いて，ジイソシアネートやメラミンとの共重合 を行いエンジニアリングプラスチックの製造を試みて いる ${ }^{15)}$ 。また小野等はフェノール化した爆砕リグニン とホルムアルデヒドとのフェノール樹脂型接着剤の合 成を試みている ${ }^{16)}$ これらはリグニンをフェノールの 代用としたものであり, 強度的にはほぼ同等の接着力 を示しているが, 溶解性やエマルジョンの形成等に問 題があり,これからの研究が期待される。

木材の総合利用に対してはリグニンの有効利用法の 開発が最も重要な課題であるが, 上述のような付加価 值の高い用途に利用される可能性が出てきたことは, 爆砕法による木材成分総合利用システムも実現に一歩 近づいたと言えよう。このように爆砕処理はこれから の省エネルギー, 省資源時代に適合した木材前処理法 であり，この早期実用化が期待される。

\section{(京都大学木材研究所 棚橋光彦)}

\section{3. リグニンの分解}

\section{1 化学的分解}

リグニンを化学的に分解してその生成物を有効利用 しょうとする試みは古くから行われており, 総説も幾 つか出ている ${ }^{17), 18) 。 ~}$

リグニンの分解反応は本来, その化学構造の研究あ るいはパルプ製造過程での反応の研究とともに確立さ れてきたため, リグニン利用の観点からの効率的な方 法は必ずしも多くはない。従って, ほとんどの場合, 経済的に有利なプロセスの開発に至っていないのが現
状である。

その理由はリグニンが芳香族系のポリマーであるた めに, 分解生成物の多くは石油製品と競合することが 多く，また生成物が多岐にわたるため原料リグニンの 違いにより組成の変化が大きいことであろう。

さらに工業原料としてのリグニンは大量に入手でき ることが条件であるが, その対象をクラフトパルプ化 廃液中のリグニンに求めた場合, 必ずしも利用可能な 原料とは言えない。このように供給される原料が特定 されていない点は, リグニン分解物利用の弱点であろ う。

これらの問題点を踏まえた上で, 現時点で将来工業 化の可能性のありそうな分解方法のうち, 特に新しい 研究成果が得られているものを概説する。

\section{1）水素化分解}

リグニン水素化分解の目的は単環フェノール類の製 造にある。

これまでに幾つかのプロセスが提案されパイロット スケールの研究まで至っているが, 結局のところ, 化 石資源からのフェノール類生産と比べて経済的利点が 認められないため実用化されていない。

これまでに開発された主なプロセスとしては, 有名 な野ロプロセス ${ }^{19)}$, Crown Zerllerbach 社の改良野口 プルロセス ${ }^{20)}$, HRI (Hydrodarbon REsaerch Inc.) 社の Lignol プロセス ${ }^{21)}$ などがあげられる。これらは いずれもリグノスルホン酸, KP リグニンを原料とし ている。化学的分解に限らず, リグニン分解物の利用 は原料リグニンの大量供給が可能で, 反応性が高いこ とが必要で, これらの条件を満たす成分分離法との繫 がりを求めにくい分解法は現実的でないと言える。

近年, 研究開発が盛んに行われるようになったオル ガハソルブパルプ化法は, 上記の観点からパルプ化廃 液中のリグニンを化学的に利用しようとするプロセス である。ソルボリシスパルプ化法もその一つで, 廃液 中のリグニンを水素化分解または熱分解して得られる フェノール類の利用を目指している22)。

表 2, 3 にこれらの主要プロセスの特徴を示した。そ れぞれに用いられる原料リグニン, 触媒は異なるが, モノフェノール収率はリグニン原料当り $30 \sim 40 \%$ に 収束している。またフェノール，クレゾールが主成分 であるが分解物はかなり広範囲に渡っている。

水素化分解の場合, リグニンに特徴的な分解物（グ アイアコール, シリンゴール系化合物）を高収率で得 られる条件を探ることが必要であろう。

\section{2）酸化分解}

酸化分解物の場合, 副生成物の利用（変性リグニン 
表 2 リグニンの水素化分解

\begin{tabular}{|c|c|c|c|c|c|}
\hline プロセス & 原 料 & 触 媒 & 溶 媒 & 水素化条件 & 生成物（収率\%） \\
\hline $\begin{array}{l}\text { 野ロプロセス } \\
\text { (野ロ研) }\end{array}$ & $\begin{array}{l}\text { 脱スルホン } \\
\text { リグニン }\end{array}$ & $\begin{array}{l}\mathrm{Fe}-\mathrm{S} \\
-\mathrm{Cu}-\mathrm{Sn}\end{array}$ & リグニンタール & $\begin{array}{l}440^{\circ} \mathrm{C}, 130 \mathrm{~atm} \\
2 \mathrm{hr}\end{array}$ & $\begin{array}{r}\text { モノフェノール+中性油 } \\
(30 \%)\end{array}$ \\
\hline $\begin{array}{l}\text { 改良野口 } \\
\text { プロセス } \\
\text { (クラウンゼラバック) }\end{array}$ & 同上 & 同上 & $\begin{array}{l}\text { フェノール+ } \\
\text { リグニンタール } \\
(1: 6.4)\end{array}$ & $\begin{array}{l}450^{\circ} \mathrm{C}, 170 \text { atm } \\
15 \mathrm{~min}\end{array}$ & $\begin{array}{l}\text { モノフェノール(21\%) } \\
\text { 中性油 }(9 \%)\end{array}$ \\
\hline $\begin{array}{l}\text { Lignol } \\
\text { プロセス } \\
\text { (HRI) }\end{array}$ & KP リグニン & $\begin{array}{l}20 \% \mathrm{Fe} / \text { ア } \\
\text { ミナ }\end{array}$ & リグニンタール & $\begin{array}{l}440^{\circ} \mathrm{C}, 70 \mathrm{~atm} \\
\text { 流通式 }\end{array}$ & $\begin{array}{l}\text { フェノール類溜分 }(38 \%) \\
\text { 中性油 }(8 \%) \text { ) }\end{array}$ \\
\hline $\begin{array}{l}\text { ソルボリシス } \\
\text { プロセス }\end{array}$ & $\begin{array}{l}\text { ソルボリシス } \\
\text { リグニン }\end{array}$ & 硫化鉄 & $\begin{array}{l}\text { シクロヘキサ } \\
\text { ノール }\end{array}$ & $\begin{array}{l}450^{\circ} \mathrm{C}, 100 \mathrm{~atm} \\
5 \mathrm{hr}\end{array}$ & $\begin{array}{l}\text { モノフェノール }(33 \%) \\
\text { モノマー合計 }(50 \%)\end{array}$ \\
\hline
\end{tabular}

表 3 モノフェノールの組成比*)

\begin{tabular}{|c|c|c|c|}
\hline 構 成 成 分 & $\begin{array}{l}\text { 改良 } \\
\text { 野口 }\end{array}$ & $\begin{array}{l}フ^{\circ} \square \\
\text { Lignol }\end{array}$ & $\begin{array}{l}\text { உス } \\
\text { ソルボリシス }\end{array}$ \\
\hline フェノール & 14.2 & 7.8 & 29.8 \\
\hline o-クレゾール & 19.0 & 6.0 & 37.6 \\
\hline$m, p^{-ク レ ソ ゙ ー ル ~}$ & 28.6 & 24.9 & 14.2 \\
\hline 2,4-キシレノール & 6.2 & 8.9 & - \\
\hline O-エチルフェール & 4.8 & - & 9.2 \\
\hline p-エチルフェノール & 15.7 & 28.8 & \\
\hline p-プロピルフェノール & 9.5 & 23.6 & 9.2 \\
\hline その他のフェノール類 & 2.0 & & \\
\hline
\end{tabular}

*)モノフェノール総収量に対する重量\%

スルホン酸塩）を除いては市場規模の小さいファイン ケミカルスとしての利用である。従ってリグニン利用 の中心にはなり得ていない。

現在のところ，工業的利用の中心はやはりリグノス ルホン酸からバニリン製造である。 SP 廃液中のリグ ニンをアルカリ雲囲気下で酸化分解して製造する（収 率数\% 10 数\%）が, 限外滤過により廃液中のリグニ ン含量を高める ${ }^{23)}$, アルカリ添加の代りに酸化白液を 用いる ${ }^{24)}$ ，またはアントラキノンのような酸化剂存在 下で酸化する ${ }^{25)}$ などにより収率が高まる。

バニリンは香料としての利用のほかに, メチルドー パ, ドーパなどの医薬品の中間体としても用いられて いる。広葉樹リグニンから得られるシリンガアルデヒ ドは，各種の医薬品中間体として注目されているトリ メトキシベンズアルデヒドの原料となる。合成経路が 短い点はリグニンを原料とするメリットがある ${ }^{26)}$ と 言えるが, 最近, 電解酸化法によって $p$-クレゾールか らトリメトキシベンズアルデヒドを高収率で合成する 方法が実用化されつつあり ${ }^{27)}$, これが医薬品としての
利用に止まるのならば, 将来的にリグニン利用として の可能性がこの分野で広がるとは考えにくい。

3）核置換反応によるカテコールの生成

以上はすでに工業化またはパイロットスケールの製 造プロセスに到達している例であるが, 基礎的研究の 段階とは言え，中間体として有用な化合物であるカテ コールの製造に関する研究も注目される。

リグニンからカテコールを製造する研究としては, 古くは Grangaad ${ }^{28)}, \mathrm{Nimz}^{29)}$ の研究があるが, 近年で は阿部, 船岡によって精力的に研究されている ${ }^{30)}$ 。この 方法は三フッ化ホウ素を触媒としてリグニンにフェ ノールを反応させ核置換, 脱メチル化反応によりカテ コールを高収率で生成するものである。

カテコール生成に至る分解反応機構はリグニン側鎖 へのフェノール化，フェノールとの核置換によるグア イアコールの生成, そしてその脱メチル化によるカテ コール生成と考えられている31332)。

この方法の特徴はフェノールの結合によりリグニン にジフェニルメタン構造が形成されれば，比較的高収 率で単一物質が製造できる点である。リグニン利用の 一つとして潜在的な可能性がある。

4) ま と め

化学的分解に限らず，リグニン分解物の利用は原料 リグニンに何を用いるかが重要であり，成分分離法と の繫がりを持たせることで現実性が増すと考えられる。

一般にリグニンからの生成物はかなり複雑多岐であ る。石油資源と抗して行くためには, 単純なフェノー ル類を効率よく製造することも一つの考え方ではある が,やはりリグニンに特徴的な生成物の収率を向上さ せることが，現在の困難な状況を打開する道であろう。 技術的には反応性の高いリグニンの分離条件の検討 と, リグニン原料に合った触媒の開発が課題となろう。 (日本紙パルプ研究所 荒木 廣) 


\section{2 熱的分 解}

リグニンの構造単位としては 3 種類が考えられるが, フェニル・プロパン構造と総称されている。石炭がべ ンゼン核の多数が縮合した複雑な構造をしているのに 対し, リグニンはこのフェニル・プロパン構造がエー テル結合 $(\mathrm{C}-\mathrm{O}), \mathrm{C}-\mathrm{C}$ 結合で繫がっている。熱分解, 水素化分解などを考える上でこの差に留意する必要が ある。本項は熱的分解の側面からリグニンの有効利用 を考察することを目的としているので, 熱分解生成物 の収率と反応条件の関係及び速度論に関する知見をま とめてみる。

リグニンの熱分解による生成物はチャー, タール, ガスであるが, それらの相対量は主に昇温速度と最終 到達温度に支配される ${ }^{33)}$ 。一般に分解速度が遅い場合 には主生成物はチャーであり, 分解速度が速くなるほ ど液状成分及びガスの収率が増大する。リグニン転換 プロセスを経済的に成り立たせるためにはリグニンを 価值の低い燃料にするのではなく,ベンゼン, フェノー ル類といった中間化成品に転換する必要があろ

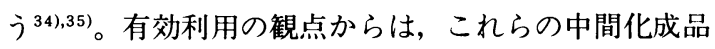
の収率の高い熱分解条件を明らかにすることが重要で あるが, 熱分解過程は燃焼, 水素化分解, ガス化, 液 化といった他の転換過程の初期段階でもあるからこの 過程を解明することは重要である。

Iatridis と Gavalas ${ }^{36)}$ はクラフトリグニンの熱分解 を試料補捉法（Captive sample technique）を用いて $400 \sim 700^{\circ} \mathrm{C} て ゙ 10 \sim 120 \mathrm{~s}$ 間行った。関与する反応の数 が多く, 反応機構及び速度パラメー夕の值がはっきり しないから, 速度論的記述はメタン以外は行われてい ない。メタンの生成はメタンの累積体積を $\mathrm{V}$ とする と，つぎの 1 次反応速度式で表すことができた。

$$
\mathrm{dv} / \mathrm{dt}=\mathrm{k}\left(\mathrm{V}^{*}-\mathrm{V}\right)
$$

ここで， $\mathrm{V}^{*}$ は熱分解温度で生成し得るメタンの全量, $\mathrm{k}$ は速度定数, $\mathrm{t}$ は時間である。彼らは分解生成物の 収率を $500 \sim 650^{\circ} \mathrm{C}$ のいくつかの温度で得ているが, 反 応時間 $30 \mathrm{~s}$ での結果を示せば図6のようである。単環 フェノールの収率は温度と共に増大するが, $650^{\circ} \mathrm{C}$ 以上 ではほとんど増大せず最大 $3.5 \%$ となった。

McDermott と Klein ${ }^{37)}$ はリグニンのモデル化合物 の分解の反応経路及び速度論を基に，モンテカルロ法 を用いてリグニン分解の数学的モデルを組立てた。

Avni ら ${ }^{38)}$ は 7 種類のリグニンを用い真空急速分解 $\left(300 \sim 1,300^{\circ} \mathrm{C}\right)$ 及び常圧定速昇温, 急速熱分解 $\left(30^{\circ} \mathrm{C} /\right.$ $\left.\min , 150 \sim 900^{\circ} \mathrm{C}\right)$ を行った。分解生成物の量はリグニ ンの種類により異なるが, 生成速度は種類にはあまり 影響されないことが分った（石炭の熱分解の場合にも

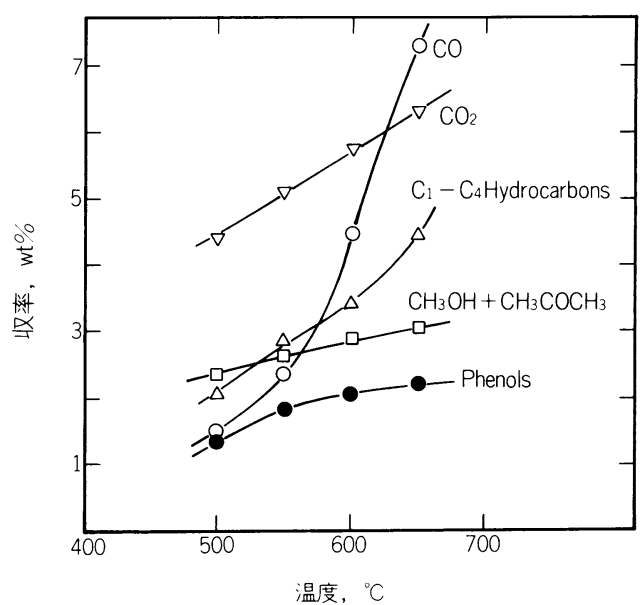

図 6 リグニン分解生成物の収率と温度の関係 (反応時間 $30 \mathrm{~s})^{36}$ )

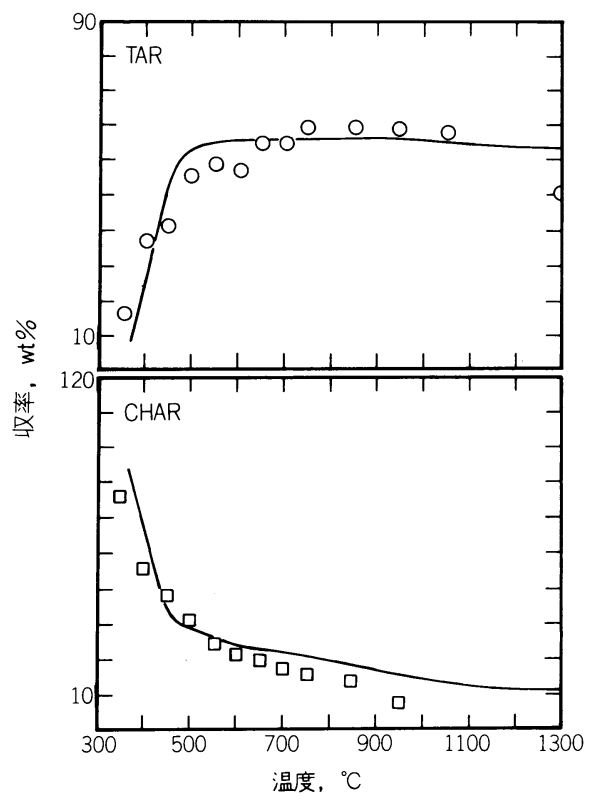

図 7 Iotech リグニンの急速熱分解による タール及びチャーの収率と最終到達温度 の関係 ${ }^{38)}$

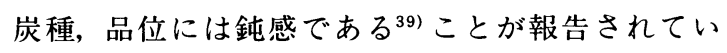
る)。彼らは石炭の熱分解モデルを基に, リグニン熱分 解のシミュレーションモデルを与えている。各成分の 生成速度は 1 次反応に従うとされており, 速度定数中 の頻度因子と活性化エネルギーが決定されている。図 7 には一例として急速熱分解時のタール及びチャーの 収率と分解温度の関係を示す。困中の実線はシミュ レーション結果を示すが, 実験点との一致は良好であ 
る。

Nunn ら ${ }^{40)}$ は $34 \mathrm{kPa}$ の $\mathrm{He}$ 雲囲気中, $600 \sim 1,400$ $\mathrm{K}$ の温度範囲で昇温速度 $1,000 \mathrm{~K} / \mathrm{s}$ においてリグニン の熱分解を研究した。 $800 \mathrm{~K}$ 以上では夕ールが主分解 生成物であり, その収率は $900 \mathrm{~K}$ で最大 $53 \mathrm{wt} \%$ を示 した後, さらに温度が上昇すると若干減少し, $1,150 \mathrm{~K}$ では $47 \mathrm{wt} \%$ となった。 $950 \mathrm{~K}$ 以上では夕ールが分解 し，ガス状成分の収率が増大する。また $800 \mathrm{~K}$ を超え るとCO がガス状成分のかなりの割合を占め, $1,440 \mathrm{~K}$ では $19 \mathrm{wt} \%$ に達する。タールを除いた主生成物の総 括的な生成速度は 1 次反応速度式によって表わされる。

最近, 佐田 ${ }^{41)}$ は窒素気流中及び溶融塩中で最終到達

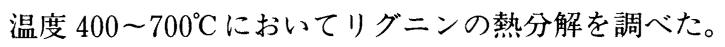
窒素気流中, 昇温速度 $400^{\circ} \mathrm{C} / \mathrm{min}, 1,000^{\circ} \mathrm{C} / \mathrm{min}$ 及び $\mathrm{NaCl}-\mathrm{KCl}$ 系溶融塩という順序で夜状生成物は単純化 され, クレゾール類が主に生成してくる。 $\mathrm{KCl}-\mathrm{ZnCl}_{2}$ 系溶融塩ではフェノール類の収率も増加する傾向が見 られた。 (京都大学工学部 熊沢英博)

\section{3 生 分 解}

1975 年に Eriksson 等 ${ }^{42)}$ がセルラーゼを欠損した白 色腐朽菌 (Sporotrichum pulverulentum) の変異株を 作出し, バイオパルピングを試行して以来, リグニン の微生物分解の研究は飛躍的に進展した。その間，(1) リグニン分解酵素の発見 ${ }^{43) 44}$, (2)リグニナーゼ(ペルオ キシダーゼの一種) の単離と同定，(3)一電子酸化（ラ ジカル）機構の解明，(4)酵素の大量生産法の開発，(5) リグニナーゼ遺伝子のクローニング, および(6)バイオ ミメティックリグニン分解法の開発へと研究が展開さ れてきた。しかしこの分野のバイオテクノロジーは長 期的展望に立っての話であり, 短期的な見通しではま だ産業的に役立つ技術は開発されていないのが現状で ある。

本項では関係分野の動向と問題点, 特に(1)リグニン 分解菌と腐朽材リグニンの特徵, (2)リグニン分解酵素 系, (3)リグニナーゼによる一電子酸化理論などについ て要約した。詳細は最近の総説等を参照された (42 53)。

\section{1）リグニン分解菌と腐朽リグニンの特徵}

リグニンに作用する主な微生物はシイタケ, エノキ 夕ケ等の担子菌（キノコ）類に属する白色腐朽菌であ る。これらは木材中のリグニンを分解するとき, 同時 に多糖類をも分解する。これに反し褐色腐朽菌は主に 多糖類を分解し、リグニンは部分分解するに過ぎない。 担子菌類に属さない軟腐朽菌は多糖類を好むが, リグ ニンを前二者の中程度に分解する。しかし, 土壌細菌
等のバクテリアのリグニン分解力は微小とされている。 現在最も注目を集めているリグニン分解菌は白色朽 菌の Phanerochaete chrysosporium (旧名 $S$. pulverulentum)である。本菌は C, N，および $\mathrm{S}$ 栄養素の欠 乏下でリグニン分解を開始する。最近，バイオテクノ ロジーの手法によってリグニナーゼの大量生産が可能 となった。

白色腐朽リグニンはChen 等によって解明され, 次 のような特徴をもつ。(1)広葉樹材リグニンの方が針葉 樹材リグニンよりも分解され易く，グアイアシルリグ ニンよりもシリンギルリグニンの方が分解され易い。

(2)腐朽材リグニンの低分子フラクションは $\mathrm{C}_{\alpha}=\mathrm{O}$ を 含み, 芳香族と脂肪族カルボン酸に富む。(3) ( $\beta-\mathrm{O}-4$ 結合の開裂，(iii側鎖 $\mathrm{C}_{\alpha}-\mathrm{C}_{\beta}$ 結合の開裂， (iii) $\mathrm{C}_{\beta}-\mathrm{C}_{\gamma}$ 結合 の開裂，(iv)芳香核の開裂， ( $\mathrm{D} \mathrm{C}_{\alpha}-\mathrm{C}_{1}$ 結合の開裂，(iv) キシル基の減少等を示す特徴をもつ。興味あることに, 芳香族カルボン酸が還元されたベンジルアルコール基 も検出され，5-5 縮合構造は意外に増加していない。

\section{2）リグニン分解醭素系}

高分子リグニンに作用する酵素系としてリグニナー ゼ，Mn依存性ペルオキシダーゼおよびラッカーゼが 知られている。前二者はプロトポルフィリンを活性中 心にもち, $\mathrm{H}_{2} \mathrm{O}_{2}$ を還元し, 二電子久損型のオキセノイ ド活性種（複合体 I）を生成する。この活性種がリグ ニンあるいは $\mathrm{Mn}$ (II) を一電子酸化する。 $\mathrm{H}_{2} \mathrm{O}_{2}$ 供給 系として, (i)グルコース-1 および-2 オキシダーゼ, (ii) 脂肪酸 $\mathrm{CoA}$ 酸化酵素, (iii) メ夕ノール酸化酵素, (iv $\mathrm{NAD}(\mathrm{P}) \mathrm{H}$ ペルオキシダーゼ, @グリオキザール酸化 酵素が知られている。

ラッカーゼは $\mathrm{O}_{2}$ を利用してフェノールを酸化する 銅含有のフェノール酸化酵素である。非フェノール性 基質には作用できないことがリグニナーゼと異なる点 である。

現在, リグニナーゼ活性は市販のベラトリルアル コールを酸化し，生成するベラトリルアルデヒドを $310 \mathrm{~nm}$ の UV 吸収増加によって測定されている。因 みにこの化合物は白色腐朽菌の二次代謝物でもある。

\section{3）リグニナーゼによる一電子酸化理論}

1985 年, 日, 米, 英, 三国からリグニナーゼによっ て触媒される $\mathrm{C}_{\alpha}-\mathrm{C}_{\beta}$ 結合開裂とそれに伴う分子状酸 素の導入反応を説明する一電子酸化理論が提案された。 図 $8^{54)}$ に示すように初発反応として $\beta-1$ リグニンモ デル基質はオキセノイド（原子状酸素型）複合体 $\left(\mathrm{Fe}^{\mathrm{v}}=\mathrm{O}\right)$ によって一電子酸化を受け，A 環または $\mathrm{B}$ 環に局在するカチオンラジカル中間体を生成する。図 示するメカニズムによって $\mathrm{C}_{\alpha}-\mathrm{C}_{\beta}$ 開裂後, 芳香族アル 


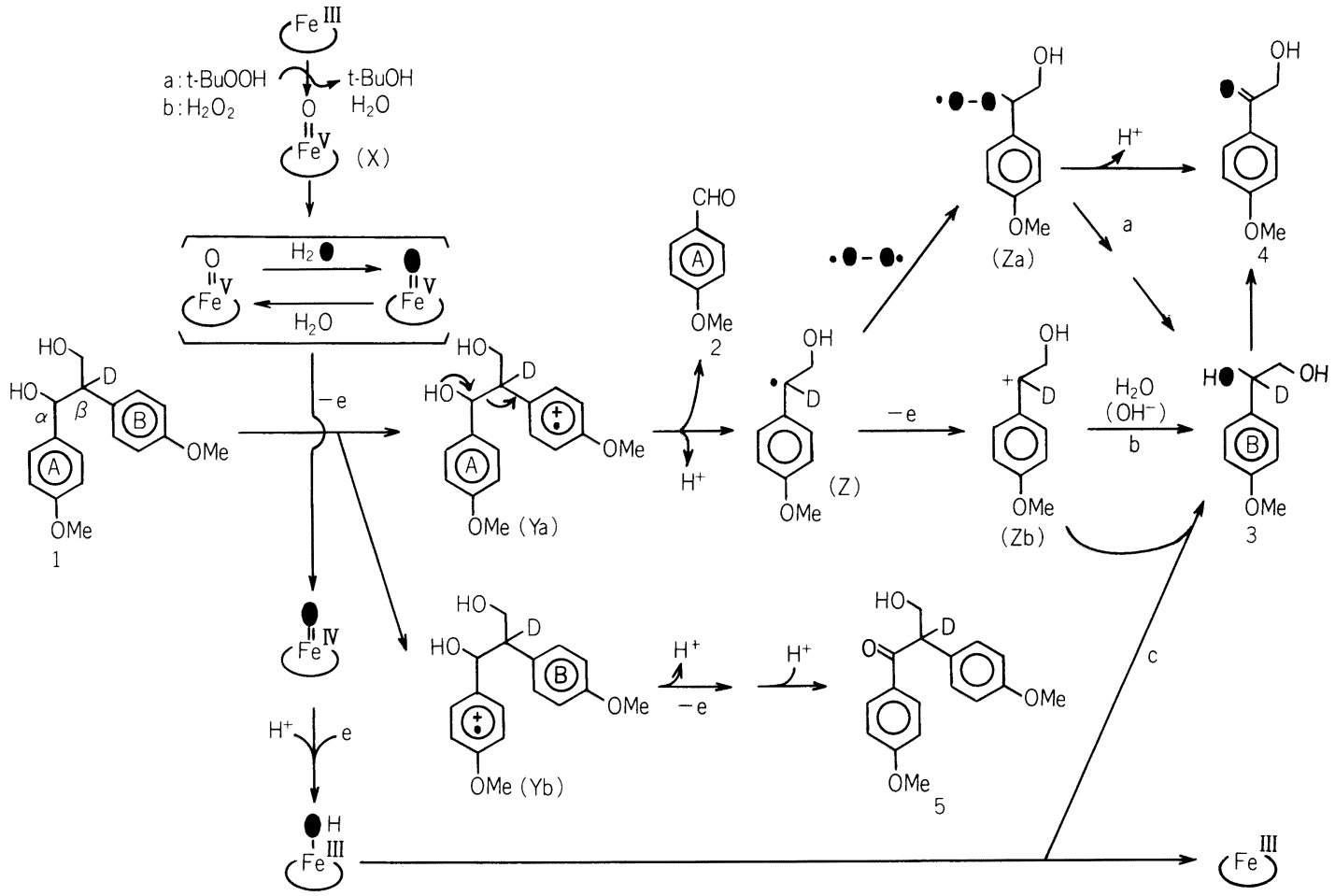

図 $8 \quad \beta-1$ モデル基質(1)の酵素的 (b) 及びバイオミメティック (a )一電子酸化機構 ${ }^{54)}$

デヒド(2)とオキシゲネーション後生成したフェニルグ リコール体(3)が生成する経路が理解できる。

ベラトリルアルコールや $\beta-\mathrm{O}-4$ 型基質のユニーク な「直接的」な開環反応や $\beta$-エーテル結合の開裂等も 一電子酸化機構によって説明される ${ }^{52)}$ 。

最近, Mn (II) ペルオキシダーゼによって生成する Mn（III）はチオール基の存在下で $\beta$-エーテル結合を 開裂するが, $\mathrm{C}_{\alpha}-\mathrm{C}_{\beta}$ 開裂をしないという新知見が報告 された。リグニン分解と関連し, Mn の役割も解明され つつある。

\section{4) 今後の展望と問題点}

上記のように, リグニンの特徴を生かした「リグニ ン化学工業」がないためか, 腐朽材リグニンの利用の 研究はほとんどなく, 紙パルプ工業と連繫したリグニ ン生分解の基礎研究が中心である。

今後も紙パ産業と関連し, 微生物触媒を活用した省 エネルギー, 無公害の技術を開発するための脱リグニ ン, パルプ漂白および排水処理と浄化の研究が重要で あるが, 次の問題点を長期的展望に立ち, 異った角度 からの総合的なアプローチが切望される。

(1)新しいリグニン分解菌の探索と遺伝子工学の応用。

リグニンだけを食べて生育する菌株を選抜または作
出する。最近, 西田等 ${ }^{53)}$ は高活性, 高選択的リグニン 分解菌 IZU を林地から単離しており注目に值する。

(2)リグニナーゼを用いた試験管内反応だけでは，リ グニンを完全分解できず，むしろ高分子化するが，自 然界の生体反応場（木材中）では, リグニンは再重合 しないか，しても容易に分解されているようであり， 脱重合ファクターの実体を解明することが重要である。 従来, セロビオースキノン酸化還元酵素が重合阻止力 があると考えられてきたが, 最近の研究では否定され つつある。

(3)微生物および酵素分解を受けた残留リグニンの化 学構造ならびに物性に関する研究。

腐朽材リグニンは森林土壤の肥沃化に寄与している が, リグニン化学の立場からのアプローチが望まれる。 森林保護と砂漠化防止に大量のリグニンが活用される ような新しい用途開発を考案することが必要である。

(4)生体反応に学ぶ新しい触媒システムの開発。

ハードなパルプ工業に微生物や酵素のソフトな技術 を融合させることは短期的には難しいので, 生体触媒 系を模倣する合理的なバイオミメティックシステム系 を研究することが重要である。例えば, リグニンの分 解に $\mathrm{H}_{2} \mathrm{O}_{2}$ が必要であることは不都合であり, $\mathrm{O}_{2}$ を活 
用するシステムに変換する方法もしくは，ビタミン $\mathrm{B}_{12}$ 酵素のように $\mathrm{O}_{2}$ も $\mathrm{H}_{2} \mathrm{O}_{2}$ を使わないで $\mathrm{C}-\mathrm{C}$ 結合 の組み換えや $\mathrm{OH}$ 基の 1,2-シフトを触媒している事 実は注目に值する。すなわち主要な $\beta-\mathrm{O}-4$ 構造は $\mathrm{C}_{\alpha^{-}}$ または $\mathrm{C}_{\gamma}$-位の $\mathrm{OH}$ 基が $\mathrm{C}_{\beta}$-位に移動すれば $\mathrm{C}_{\beta}$-位は ヘミケタール構造となり，容易に元のエーテル結合は 開裂する。逆に, $\mathrm{C}_{\beta}$ のアリル基が $\mathrm{C}_{\alpha}$ または $\mathrm{C}_{\gamma}$ 位に転 移しても，難分解性エーテル結合は開裂する。

最近，筆者等はリグニナーゼのモデルとして新しい バイオミメティック触媒 $(\mathrm{Mn} /$ 過酢酸) 系を開発する ことに成功し, KP の無塩素漂白にも応用できること を実証した ${ }^{55)}$ 。現在, 紙八゚研との共同開発研究として進 展していることを付記する。

自然界では植物はポルフィリンを使ってリグニンを ラジカル重合し, 菌類はポルフィリンを使ってリグニ ンを分解している。実に合理的なりグニンの生合成と 生分解の循環系が想像される。今後ますます，森林資 源と環境に調和した技術開発研究が重要となることを 確信する。 (京都大学木材研究所島田幹夫)

\section{4. 分解物利用の可能性}

\section{1 はじめに}

リグニンはフェニルプロパンを主とするランダムポ リマーであり，多くの研究者が種々のモデル構造を提 案しているが56 59)，いずれも完全なものではないと言 われている。またりグニンの利用方法としては，(1)紙 にすきこんでしまう，(2)燃料として燃やす，(3)高分子 のまま（少し改質して）利用する，(4)低分子に分解し て利用する，という4つの方向が考えられる。

日本のパルプ生産高は表 $4^{60)}$ のとおりで約一千万 $\mathrm{t}$ である。GP, RGP, TMP, SCPはリグニンをパル

表 4 日本のパルプ生産高 (昭和 62 年) ${ }^{60)}$

\begin{tabular}{|c|c|c|c|}
\hline & 種 & 生 産 高 & 割 合 \\
\hline & クラフト & $7,384,773 \mathrm{t}$ & $75.9 \%$ \\
\hline 製 & サルファイト & 28,111 & 0.3 \\
\hline 紙 & セミケミカル & 193,822 & 2.0 \\
\hline 用 & ケミグラウンド & 252,206 & 2.6 \\
\hline パ & サーモメカニカル & 708,604 & 7.3 \\
\hline ル & リファイナーグラウンド & 345,193 & 3.5 \\
\hline $7^{\circ}$ & 砕 木 & 628,815 & 6.4 \\
\hline & その他 & 15,939 & 0.2 \\
\hline & 挥パルプ & 175,272 & 1.8 \\
\hline 合 & 計 & $9,732,735$ & 100.0 \\
\hline
\end{tabular}

表 5 リグニン製品用途別需要量611 (昭和 61 年度推定値)

\begin{tabular}{|c|c|}
\hline 用 & 需要量 $(\mathrm{t} / \mathrm{Y})^{*}$ \\
\hline コンクリート混和剤 & 100,000 \\
\hline 肥料用造粒剂 & 16,000 \\
\hline 染料用分散剤 & 15,000 \\
\hline 鉱業用粘結剤 & 14,000 \\
\hline 農薬用添加剂 & 4,000 \\
\hline 窯業用添加剤 & 4,000 \\
\hline その他 & 13,000 \\
\hline 合 計 & 166,000 \\
\hline
\end{tabular}

*50\%濃縮液換算

プの中に混ぜる方向での利用であり，KP は燃料とし ての利用である。SPリグニンの一部は(3)(4)の方向で 利用されているが，パルプとしては KP におされぎみ で生産量は年々下降している。表 $5^{61)}$ に日本のリグニ ンの利用について示した。これは殆どが SPリグニン で不足分は輸入している。取りだされるリグニンの形 態の相違から，KP リグニンでSP リグニンを代替す るということは行われていない。ここではKPリグニ ンの利用という面から考えてみたい。かなり乱暴な推 論もあるかと思うが御容赦願いたい。

\section{2 リグニンの価格}

表 4 に示した通り KP の割合は圧倒的であり, 生産 されるパルプの約半分がリグニンと考えられるので, 年間 360 万 $\mathrm{t}$ のリグニンが $\mathrm{KP}$ プロセスで燃やされて いる勘定になる。構造の種々のモデルから分かる通り リグニンはそれなりの化学構造を持っているので何と かそれを生かせないかというのが，積年のテーマであ る。

図 9 に標準的な KP プロセスの簡略化したフローを 示した。LKP $1 \mathrm{t}(\mathrm{AD})$ 生産するために $3.2 \mathrm{t}$ の L 材 チップを使用する。チップ中の固形分は $1,930 \mathrm{~kg}$, そ の内パルプとして $900 \mathrm{~kg}$, パルプに付着して次工程に もちだされる固形分が $19 \mathrm{~kg}$ であり, 残り $1,011 \mathrm{~kg}$ は 回収ボイラーに送られて熱源として利用されている。 そのうち利用可能なリグニンは $400 \mathrm{~kg}$ と仮定して話 しを進める。回収ボイラーでは電力および低圧蒸気を 生産しているが, 蒸解・洗浄等系内で消費するほかに, 他の工程に余剩の電力・蒸気を供給している。それら を金額に換算して議論を進める。当然のことながら価 格には变動があり, また蒸気, 電力単価は各工場で独 自に計算しているが, 大体妥当な数値を当てはめてみ 


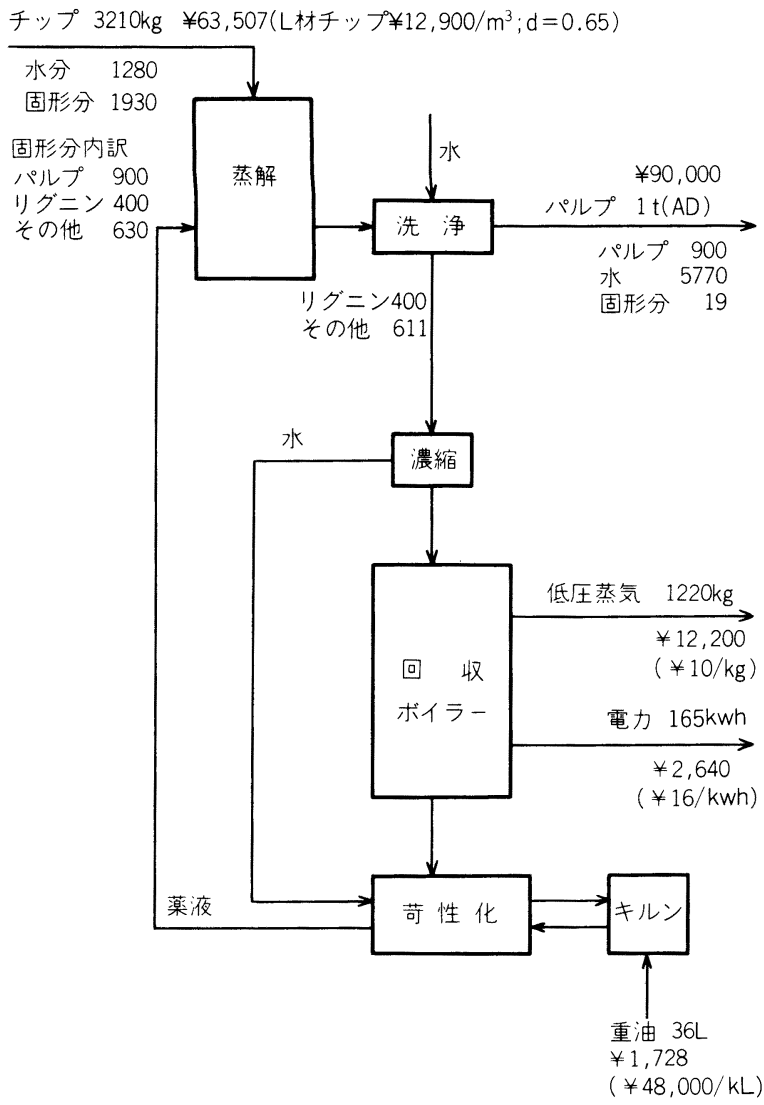

図 9 クラフトプロセスのフローバランス (パルプ $1 \mathrm{ADt}$ 当たり)

表 6 リグニンの価格試算

(1)余㮃の蒸気・電力相当のリグニンを利用する場合

\begin{tabular}{|c|c|c|c|c|c|c|}
\hline \multicolumn{3}{|r|}{$\begin{array}{c}\text { 単位当りの } \\
\text { 熱 量 }\end{array}$} & 単 価 & 余 剰 分 & 換算熱量 & 金 額 \\
\hline 電 & 力 & $860 \mathrm{kcal} / \mathrm{kWh}$ & $¥ 16 /$ kwh & $165 \mathrm{kwh}$ & $141,900 \mathrm{kcal}$ & $¥ 2,640$ \\
\hline 蒸 & 気 & $670 \mathrm{kcal} / \mathrm{kg}$ & $¥ 10 / \mathrm{kg}$ & $1,220 \mathrm{~kg}$ & $817,400 \mathrm{kcal}$ & $¥ 12,200$ \\
\hline & & 計 & & & $959,300 \mathrm{kcal}$ & $¥ 14,840$ \\
\hline
\end{tabular}

$959,300 \mathrm{kcal} \div 6,900 \mathrm{kcal} / \mathrm{kg}=139.0 \mathrm{~kg}$ $¥ 14,840 \div 139.0 \mathrm{~kg}=¥ 106.8 / \mathrm{kg}$

(2)グニンを全量ぬきだし，重油を補う場合

$(400 \mathrm{~kg}-139 \mathrm{~kg}) \times 6,900 \mathrm{kcal} / \mathrm{kg} / 9,900 \mathrm{kcal} / \mathrm{L}=181.9 \mathrm{~L}$

$181.9 \mathrm{~L} \times ¥ 48 / \mathrm{L}=¥ 8,731$

$(¥ 8,731+¥ 14,840) / 400 \mathrm{~kg}=¥ 58.9 / \mathrm{kg}$

(3)グニンを熱量をもとに重油に換算した場合

$6,900 \mathrm{kcal} / \mathrm{kg} \div 9,900 \mathrm{kcal} / \mathrm{L}=0.697 \mathrm{~L} / \mathrm{kg}$

$¥ 48 / \mathrm{L} \times 0.697 \mathrm{~L} / \mathrm{kg}=¥ 33.5 / \mathrm{kg}$ 
た。低圧蒸気・電力・リグニン・重油を熱量に換算す ると，それぞれ， $670 \mathrm{kcal} / \mathrm{kg}, 860 \mathrm{kcal} / \mathrm{kwh}, 6,900$ $\mathrm{kcal} / \mathrm{kg}, 9,900 \mathrm{kcal} / \mathrm{L}$ となる。リグニンの利用に当た り, リグニンの価值がどの程度かを熱量を共通の尺度 にした計算例を表 6 に示した。どのような利用の仕方 をするかでリグニンの価格が異なる。KPプロセスに 組み込んだほうがリグニンの価值が高くなるが，これ は翻って言えば KPプロセスがそれだけ完成されたプ ロセスであることを示している。

\section{3 量の持つ意味}

リグニンからフェノール類を生産することを考えて みる。 Nimzのモデル ${ }^{56)}$ をもとに, ベンゼン環部分が 総てフェノール $\left(\mathrm{C}_{6} \mathrm{H}_{5} \mathrm{OH}\right)$ になると仮定すると，

$\left(25.5 \times \mathrm{C}_{6} \mathrm{H}_{5} \mathrm{OH}\right) /\left(\mathrm{C}_{279.1} \mathrm{H}_{301.4} \mathrm{O}_{98}\right)=0.4593$ となり, $1 \mathrm{~kg}$ のリグニンから約 $460 \mathrm{~g}$ のフェノールが とれる。実際, Lignol 法 ${ }^{20162)}$ というプロセスが実験さ れておりこれによるとフェノール類は混合物として $37.5 \%$ 生成する。フェノール類の生産高と価格を表 $7^{63)}$ に示した。現在, フェノールはべンゼンの酸化ま たは石油ピッチの熱分解で得られている (タール酸)。 Lignol 法を改良して, 全部純粋なフェノールになった とすると $1 \mathrm{~kg}$ のリグニンから $0.46 \mathrm{~kg}$ のフノール がとれる。フェノールの価格を 220 円 $/ \mathrm{kg}$ とすると, 1 $\mathrm{kg}$ のリグニンから 101 冈相当の製品が得られること になるが, リグニンの抜き取り，分解のコストを考え ると一部のみの利用（表 6 (1)）では引き合わない。リ グニンを総てフェノールの生産に振り向けると仮定す る(表 6 (2))。KP プラントはだいたい $500 \mathrm{t} /$ 日 $=60$ 万 $\mathrm{t} /$ 年であり,リグニンの産出量は 30 万 $\mathrm{t} /$ 年となり, 一 つのプラントだけで年間 13 万 $\mathrm{t}(30$ 万 $\mathrm{t} \times 0.46)$ のフェ ノールができる。昭和 62 年度の日本のフェノールの生 産量は約 30 万tであり生産過剩は明らかである。

一方，フェノールまで分解してしまったら，植物材 料という特徴がなくなるという議論もある。表 $8{ }^{63)}$ に

表 7 フェノール類の生産量と価格 ${ }^{63)}$

\begin{tabular}{|c|c|c|}
\hline & $\begin{array}{l}\text { 生 産 } \text { 量 } \\
\text { (昭和 } 62 \text { 年) }\end{array}$ & 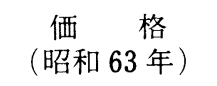 \\
\hline フェノール & $307,773 \mathrm{t}$ & $¥ 190 \sim 250 / \mathrm{kg}$ \\
\hline o-クレゾール & 1,713 & \\
\hline m-クレゾール & 4,587 & $¥ 430 \sim 480$ \\
\hline p-クレゾール $(80 \%)$ & 7,362 & $¥ 800 \sim 850$ \\
\hline $\begin{array}{c}\text { キシレノール酸 } \\
\text { (タール系) }\end{array}$ & 1,498 & $¥ 250 \sim 260$ \\
\hline ベンゼン & $2,417,662$ & $¥ 82 \sim 87$ \\
\hline
\end{tabular}

表 8 メトキシル基を持つ化合物の生産量63) (昭和 62 年) と価格(昭和 63 年 7 月)

\begin{tabular}{|c|c|c|}
\hline 化 合 物 & 価 格／製 法 & 需要量／用途 \\
\hline $\begin{array}{l}\text { グアヤコ } \\
\text { ール }\end{array}$ & $\begin{array}{l}¥ 1,500 / \mathrm{kg} \\
\text { カテコールのメチ } \\
\text { ル化 }\end{array}$ & $\begin{array}{l}650 \mathrm{t}(300 \mathrm{t} \text { 輸出 }) \\
\text { 香料 } \\
\text { 医薬品原料 }\end{array}$ \\
\hline バニリン & $\begin{array}{l}¥ 6,500 \sim 7,000 / \mathrm{kg} \\
\text { 植物から抽出 } \\
¥ 3,300 \sim 3,500 / \mathrm{kg} \\
\text { リグニンの分解 }\end{array}$ & \multirow{2}{*}{$\begin{array}{l}\text { 香料 } \\
\text { 医薬品原料 } \\
470 \mathrm{t} \\
\text { 香料 }\end{array}$} \\
\hline $\begin{array}{l}\text { エチルバ } \\
\text { ニリン }\end{array}$ & $\begin{array}{l}¥ 5,500 \sim 6,000 / \mathrm{kg} \\
\text { シュウ酸から合成 }\end{array}$ & \\
\hline $\begin{array}{l}\text { オイゲノ } \\
\text { ール }\end{array}$ & $\begin{array}{l}¥ 3,700 \sim 3,900 / \mathrm{kg} \\
\text { 植物から抽出 }\end{array}$ & $\begin{array}{l}145 \mathrm{t} \\
\text { 香料 } \\
\text { 医薬品原料 }\end{array}$ \\
\hline $\begin{array}{l}\text { イソオイ } \\
\text { ゲノール }\end{array}$ & $\begin{array}{l}¥ 4,100 \sim 4,600 / \mathrm{kg} \\
\text { 植物から抽出 }\end{array}$ & $\begin{array}{l}10 \mathrm{t} \\
\text { 香料 }\end{array}$ \\
\hline $\begin{array}{l}\text { アニスア } \\
\text { ルデヒド }\end{array}$ & $\begin{array}{l}¥ 3,000 \sim 3,500 / \mathrm{kg} \\
\text { アネトールの酸化 } \\
\text { p-クレアゾールか } \\
\text { ら合成 }\end{array}$ & $\begin{array}{l}100 \mathrm{t} \\
\text { 香料 } \\
\text { 医薬品原料 }\end{array}$ \\
\hline $\begin{array}{l}\text { アネトー } \\
\text { ル }\end{array}$ & $\begin{array}{l}¥ 3,000 \sim 4,000 / \mathrm{kg} \\
\text { 植物から抽出 }\end{array}$ & $\begin{array}{l}10 \mathrm{t} \\
\text { 香料 } \\
\text { 医薬品原料 }\end{array}$ \\
\hline
\end{tabular}

メトキシル基をもった化合物の生産量と価格を示した。 メトキシル基をもなないフェノール類に比べて 1 桁高 価格であるが需要量は少ない。たとえば，バニリンは $\mathrm{SP}$ リグニンから 10〜15\%の収率で得られる。SP の生 産高は $28,000 \mathrm{t}$ であり, リグニン産出量は $14,000 \mathrm{t}$ と して，10\%の収率でバニリンが得られるとすると， $1,400 \mathrm{t}$ 生産可能である。ところがバニリンの需要量は $500 \mathrm{t}$ どまりである。KPリグニンからバニリンをつく る有力な手段を考えたとしても，大量のリグニンを捌 けそうにはない。

\section{4 エンジニヤリングプラスチックをめさして}

香料や医薬品原料を目標とする限りは市場規模から の制約を受ける。市場規模の大きなものでは汎用プラ スチックスということになるが，価格の面で難点があ る。そこで，もうすこし高機能性のエンジニヤリング プラスチックに目を向けてみる。五大エンプラの一つ にポリオキシフェニレン（別名ポリフェニレンオキシ ド : PPO) があり，これは 2,6 -キシレノールを酸化重 合して合成され, 耐熱性, 寸法安定性にすぐれ，これ 


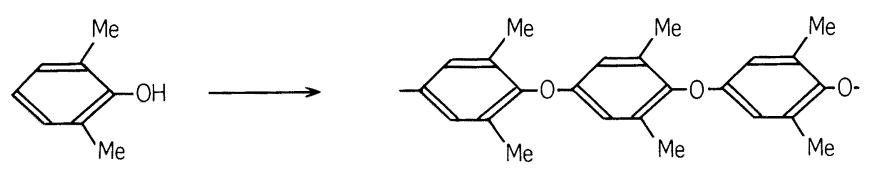

2,6-Xytenol

PPO : Poly (oxy-2,6-dimethyl-1,4-phenylene)

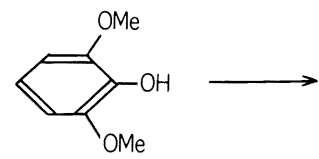

Syringol

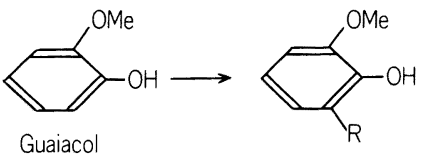

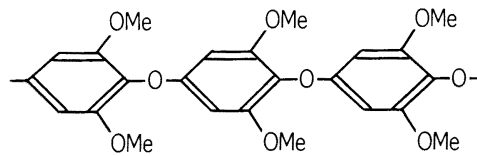

Poly (oxy-2,6-dimethoxy-1,4-phenylene)

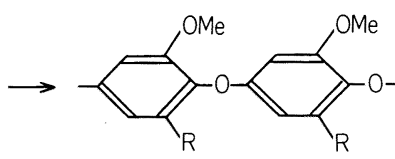

図 10 ポリオキシフェニレンの合成

からも需要の伸びが期待される。欠点は成型性が悪く, 耐熱性を犠牲にしてポリスチレンと混合して（約 1 ： 1）変性 PPO として使用されている。OA 機器, 自動 車, 電気・電子部品の需要が多く, これらの分野は今 後とも発展することが確実であり, 従って PPOの需 要も年 $10 \%$ 程度の増加が見込まれている。昭和 60 年 度の使用量は $45,000 \mathrm{t}$ であったが，日本における現在 の生産能力は PPOで $85,000 \mathrm{t}$ といわれている ${ }^{64)}$ 。変 性 PPO の価格は 650 1,000 円/kgで, ポリスチレン が 250〜300 円/kg なので PPO 単独では 1,500 円/ kg 位だと思われる。

PPO がエンジニヤリングプラスチックスとしての 地位を獲得するまでに，2,6-キシレノール以外のフェ ノール類についても多くの研究がなされた。2,6-位に 置換基を持つフェノールであれば PPO と同系統のポ リマーを合成することができて，だいたい似通った性 質を持つ。また 4 位が未置換のフェノールであれば, やはり同系統のポリマーが合成できる(図 10)。シリン ゴールからもポリオキシフェニレンが合成されており, $\mathrm{Tg}$ は PPO と比較すると約 $35^{\circ} \mathrm{C}$ 下回わるが, それでも $150^{\circ} \mathrm{C}$ 以上であり ${ }^{65)}$, 耐熱性としては十分である。さら に成型性などは若干良いと思われる。今までシリン ゴールにはあまり注意が向けられていないが, その原 因はシリンゴールが原料としては手に入れにくかった ためと思われる。また若干の研究結果からは, 特に注 目すべき性質も見出されていないせいでもある。しか しながら, シリンゴールから誘導したポリオキシフェ ニレンはある程度の価格で供給できるならば, 機能の 面では十分にPPOに対抗できるポリマーだと考えら れる66)。

$\mathrm{Nimz}$ のモデル56) をもとに, シリンギル核は総てシ
リンゴールになり, グアヤシル核は総てグアヤコール になるとすると, $1 \mathrm{~kg}$ のリグニンから約 $310 \mathrm{~g}$ のシリ ンゴールがとれ，また約 $350 \mathrm{~g}$ のグアヤコールがとれ る。グアヤコールはそのままではポリオキシフェニレ ン型のポリマーにはならないが，オルト位に置換基を 導入することにより可能である。酸化重合の収率を 90\%まで向上可能だとすれば, そしてポリオキシフェ ニレンの価格を 1,500 円 $/ \mathrm{kg}$ と見積るとリグニン 1 $\mathrm{kg}$ から 400 円相当のポリオキシフェニレンができる。 60 万t/年のプラントで余剩リグニンが 8 万 $\mathrm{t}(=$ $600,000 \mathrm{t} \times 0.139=83,400 \mathrm{t})$ でるとして, 約 2 万 $\mathrm{t}$ $(83,400 \times 0.313 \times 0.9=23,493:$ 約 350 億円)のポリオ キシフェニレンを生産することになる。

\section{5 おりに}

リグニンを $\mathrm{kg}$ 当たりいくらに評価するかは, はじ めに述べたように使用量の関数になると思われる。で きるだけ多量のリグニンを利用し, 不足する熱量は重 油で補うほうが経済的に有利である。高付加価值製品 といっても，市場規模は無視しえない。リグニンを抜 き出して, 別の製品にする際の分離・合成のエネルギー をどう見積るかについての検討もしていないが, この 程度の価格と市場を持つ製品をめざす必要があろう。

(日本紙パルプ研究所 重本匡史)

\section{引用文献}

1）小宮山宏, 平塚茂雄（編）：化学工学, 49, 756 (1985)

2) Sakakibara, A. : Wood Science \& Technology, 14, 89 (1980)

3）近藤民雄：「リグニンの化学」(中野準三編, ユ二 広報), p.7 (1979) 
4) Tanahashi, M. ; Tamabuchi, K. ; Goto, T. ; Aoki, T. ; Karina, M. ; Higuchi, T. : Wood Research, 75, 1 (1988)

5）志水一允：紙八゚技協誌，42，1114(1988)

6) Tanahashi, M. ; Karina, M. ; Tamabuchi, K. ; Higuchi, T. : Mokuzai Gakkaishi, 35, 135 (1989)

7) Tanahashi, M. ; Goto, T. ; Horii, F. ; Hirai, A. ; Higuchi, T. : Mokuzai Gakkaishi, to be published.

8) Lonikar, S. V. ; Shiraishi, N. ; Yokota, T. ; Tanahashi, M. ; Higuchi, T. : J. Wood Chem. Technol., 4, 483 (1984)

9) Okajima, K. ; Kamide, K. : abstracts of CELLUCON 88 JAPAN, p.18 (1988)

10) Rotsein, O. D. ; Key, R. M. ; Wayman, M. ; Strasberg, S. M. : Gastroenterology, 81, 1098 (1981)

11）矢澤 到, 野澤美津子, 柿島 博, 西島 靖, 棚 橋光彦, 樋口隆昌：第 31 回リグニン討論会(京都) 講演要旨集, p.141 (1986)

12) Brekhman, I. I. ; Dardymov, I. V. : Lloyia, 32, 46 (1969)

13) Tanahashi, M. ; Karina, M. ; Higuchi, T. : Mokuzai Gakkaishi, to be published.

14) Sudo, K. ; Shimizu, K. : Fourth ISWPC, Vol 1, 101 (1987)

15）小野拡邦, 須藤賢一, 唐沢仁志, 桃 折 : 第 32 回リグニン討論会(福岡)講演要旨集, p.147(1987)

16) Newman, W. H. ; Glasser, W. G. : Holzforschung, 39, 345 (1985)

17）榊原 彰：「ウッドケミカルスの先端技術と展 望」, (シーエムシー), p.182（1983）

18）山田雅稔, 岡部次郎, 秦 邦男;「木材の化学」 (中野準三編，二二広報)，p.347 (1978)

19）大島ら：野口研技報, 14 号, 26 (1966)

20) Goheen, D. G. : “Advanced in Chemistry Series (ACS) ", 59, p.205 (1966)

21) Hellwig, K. C. ; Alpert, S. B ; Johnson, C. A. ; Schuman, S. C. : "Production of Phenols from Lignin”, Tappi Annual Meeting, N.Y. (1969)

22）可知省吾，土屋 寞：紙八技協誌，投稿中

23） 日本公開特許公報 特開 昭 51-12388

24） 日本公開特許公報 特開 昭 52-134147

25）日本公開特許公報 特開 昭 55-35999

26）日本公開特許公報 特開 昭 48-56637

27）現代化学：4 月号, p.12（1985）
28) Grangaad, H. : Tappi, 44, 433 (1961)

29) Nimz, H. and Das, K. : Chem. Ber., 104, 2359 (1971)

30） 日本公開特許公報 特開 昭 50-30748

31）船岡正光，阿部 勲，木材誌：28，255（1982）

32) 阿部 勲, 船岡正光: 昭和 60 年度科学研究費補助 金（特定研究）研究成果報告書

33) Probstein, R. F. ; R. E. Hicks : "Synthetic Fuels", Chapter 8, McGraw-Hill (1982)

34) Goldstein, I. S. : J. Polym. Sci. (Appl. Polym. Symp.), 28, 259 (1975)

35) Drew, S. W. ; Kadam, K. L. ; Shoemaker, S. P. ; Glasser, W. G. ; Hill, P. : AIChE Symp. Ser. No. 181, 74, 21 (1978)

36) Iatridis, B. ; Gavalas, G. R. : Ind. Eng. Chem. Prod. Res. Dev., 18, 127 (1979)

37) McDermott, J. B. ; Klein, M. T. : Chem. Eng. Sci., 41, 1053 (1986)

38) Avni, E. ; Coughlin, R. W. ; Solomon, P. R. ; King, H. H. : Fuel, 64, 1495 (1985)

39) Suuberg, E. M. ; Peters, W. A. ; Howard, J. B. : Ind. Eng. Chem. Process Des. Dev., 17, 37 (1978)

40) Nunn, T. R. ; Howard, J. B. ; Longwell, J. P. ; Peters, W. A. : Ind. Eng. Chem. Process Des. Dev., 24, 844 (1985)

41）佐田栄三：未発表

42) Ander, P.; Eriksson, K. E. : Svensk Papperstidn., 78, 643 (1975)

43) Tien, M. ; Kirk, T. K. : Science, 221, 661 (1983)

44) Glenn, J. K. ; Morgan, M. A. ; Mayfield, M. B. ; Kuwahara, M. ; Gold, M. H. : Biochem. Biophys. Res. Commun., 114, 1077 (1983)

45) Shimada, M. ; Habe, T. ; Umezawa, T. ; Higuchi, T. ; Okamoto, T. : Biochem. Biophys. Res. Commun., 122, 1247 (1984)

46) Higuchi, T. : Biosynthesis and Biodegradation of Wood Components, Academic Press, New York (1985)

47) Buswell, J. A. ; Odier, E. : CRC Critical Reviews in Biotechnology, 6, 1 (1987)

48) Kirk, T. K. ; Farrell, R. L. : Ann. Rev. Microbiol., 41, 465 (1987)

49) Odier, E. : Lignin enzymic and microbial degradation, INRA Publications (1987)

50）桑原正章：木材誌，32, 567 (1986) 
51）諸星紀幸：紙八技協誌，41，119（1987）

52) Umezawa, T. : Wood Research, No.75, 21 (1988)

53) Nishida, T. ; Kashino, Y. ; Katayama, Y. ; Mimura, A. ; Takahara, Y. : 木材誌 35, 144 (1989)

54) Shimada, M. ; Habe, T. ; Higuchi, T. ; Okamoto, T. ; Panijpan, B. : Holzforschung, 41 (5) 277 (1987)

55）島田幹夫, 樋口隆昌: 第 39 回日本木材学会大会 (沖縄) 研究発表要旨集, p.359（1989）

56) Nimtz, H. : Angew. Chem. Int. Edit., 13(5) 313 (1974)

57) Glasser, W. G. ; Glasser, H. R. : Holzforschung,
28(1) 5 (1974)

58) Freudenberg, K. : Holzforschung, 18(1/2) 3 (1964)

59) Freudenberg, K. : Science, 148, 595 (1965)

60）紙パルプ統計年報, 昭和 62 年, p.24 通産大臣官 房調查統計部編

61）八巻真覧：紙と周辺技術 3(1）39（1988）

62) C \& E News, Nov.3 p.35 (1980).

63）「10889 の化学商品」化学工業日報社 (1988)

64）日経ニューマテリアル 36，60（1987.11.16）

65) Jauhiainen, T. : Makromol. Chem., 183, 915 (1982)

66）重本匡史, 伊藤和彦：紙八゚技協誌, 投稿準備中

\section{製紙内填用軽質炭酸カルシウム T
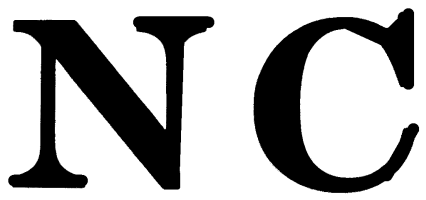 \\ Toyo Neutral Calcium Carbonate}

1. 銘 柄

\begin{tabular}{|c|c|c|}
\hline 銘 & 含有水分 (\%) & 粉体性状 \\
\hline $\begin{array}{lll}\mathrm{T} & \mathrm{N}\end{array}$ & 0.5 以下 & 乾燥粉体品 \\
\hline TNC-CIO & 35 以下 & 湿り粉体状品 \\
\hline TNC-C30 & 35 以下 & 湿り粉体状品 \\
\hline
\end{tabular}

新しいニーズに、新しい時代を創る…

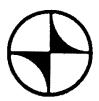

\section{2. 特 徵}

○高不透明性・白色度の付与

○ワイヤーやカッターの低磨耗性

○高内﨏時の紙力強度の低下抑制

○湿り粉体状にて粉塵等の環境改善

○平滑性の付与

本 社 7780 高知市萩町 2 丁目 2 番 25 号

TEL (0888)31-1241(代)

FAX (0888) 33-2250

東京支店 - 大阪支店 - 名古屋営業所 九州営業所 